https://doi.org/10.22364/htqe.2021.70

\title{
THE BOOK “DIE KAVALIERE VON ILLUXT”. THE NEW DISCOVERY FOR XXI CENTURY READER
}

\author{
Valentina Talırko \\ Daugavpils University, Latvia
}

\begin{abstract}
The article examines the historical and literary significance of the memoirs of a Baltic German about Latgale. The space between Ilukste and Daugavpils has been little studied. The data about individual estates and their owners is fragmentary. The study is a separate part of a large regional and literary study dedicated to the Baltic Germans living in the territory of Latgale and in Daugavpils region. The aims of the study are to establish a connection between the text of the book and geographical and personal realities, as well as to reveal the relationship of the Baltic Germans with the population of Latgale from a perspective of self-reflection. Understanding "myself" in the eyes of others and "others" in one's personal perception is getting more relevant as studying these interactions on the basis of literary texts opens for understanding of the current processes in modern society. The specific tasks are to promote a national issue on the material of the given text as well as to determine a link between the memoir text and the jokes of the Baltic Germans (Pratchen), the features of which have been defined in the authorized studies.

The text is understood as an object of scientific cognition in which there are no random linguistic or substantive units. The methodology of research is based on the interpretation of a literary text as well as the synthesis of statistical analysis, immanent critique and content analysis. In the course of the study, it was possible to establish a structural and substantive link between individual episodes of the book with the Baltics jokes (Pratchen).

For the peoples who inhabited Latgale (southeastern part of Latvia) in the $18^{\text {th }}$ and $19^{\text {th }}$ centuries, the national issue was not decisive, especially among rural people. Difference in perception of oneself and "myself" in the eyes of others was determined by different social status: Germans are the landowners, the rest are servants and badgers. The mental character of the Baltic Germans was shaped, first and foremost, by the family upbringing and education level, commonly university. The key values were love for their native land, pride for their ancestors, honor and service to the state, and faithfulness to the word. On the basis of the life realia described in the book, it is possible to reconstruct the way of life of the people who disappeared from the map of modern Latgale.

The research is funded by the Latvian Council of Science, project "The Baltic Germans of Latgale in the context of socio-ethnic relations from the $17^{\text {th }}$ till the beginning of the $20^{\text {th }}$ century" project No. Izp-2020/2-0136.
\end{abstract}

Keywords: Baltic Germans, Die Kavaliere von Illuxt, geographical and personal realities, Latgale, Pratchen. 


\section{Introduction}

Despite the fact that a few years ago the texts of the Baltic Germans were in the focus of attention of many researchers (Michael Garleff, Wilfried Schlau, York-Gothard Mix, Jürgen Wolff, Gero von Wilpert, Anja Wilhelmi, Benedikts Kalnačs, Māra Grudule, etc.), many issues still remain either not fully studied, or not considered deeply enough. First of all, the issues of linguistic originality and the tragic fate of the Baltic Germans, who left their homeland in 1939, were considered. In the last decade, Anja Wilhelmi has been actively involved in family issues in Northern Europe, from whose pen several works were published on the fate of Baltic women and family politics in the $18^{\text {th }}-20^{\text {th }}$ centuries (Wilhelmi, 2008). Most of the said researchers concentrate on global problems and the study of the population of large cities, leaving aside regional features and problems. There is still no significant research dedicated to the peculiarities of the life of the Baltic Germans in areas where their concentration had been less pronounced should one compare, for instance, with Riga, Jelgava, or Cesis. The study is a separate part of a large regional and literary study dedicated to the Baltic Germans living in the territory of Latgale and, wherever possible, in the region of the city of Daugavpils. As stated in the previous research, these were the families of the Tiesenhausens, Hahns, Borchs, Engelhardts etc. An examination of the Latvian newspapers dating back to the 1930s revealed that the names of the Baltic Germans appeared only in the criminal and death records. In the fiction of the Baltic Germans, Daugavpils and Latgale in general are hardly mentioned. Nevertheless, the remnants of the former Baronian estates indicate that the Baltic Germans lived here for generations. Interest in the heritage of the Baltic Germans in the region has been particularly high in the last decade owing to the active engagement of researchers at the University of Daugavpils. This article focuses on the work Die Kavaliere von Illuxt (1949) by Alexis von Engelhardt (Engelhardt, 1949), dedicated to the family and friends of the Engelhardts, who lived in the area of Ilūkste, $25 \mathrm{~km}$ away from the largest city of Latgale, Daugavpils. The aim of the study is to link the text of the book with geographical and personal realia, as well as to reveal the relations of the Baltic Germans with the locals of Latgale from the perspective of self-reception. Understanding "myself" in the eyes of others and "others" in one's personal perception is getting more relevant today, as studying these interactions on the basis of literary texts gives us understanding of the current processes in contemporary society. One of the specific tasks of the research is to determine the link between the memoir text and the jokes of the Baltic Germans (Pratchen), the features of which had been defined in the authorized studies. Despite the relatively large number of Pratchen texts, they still constitute a scientific lacuna. 


\section{Method}

The text is understood as an object of scientific cognition, in which there are no random linguistic and substantive units. The methodology of research is based on the interpretation of a literary text as well as the synthesis of statistical analysis, immanent critique and content analysis in critical perception of the text. The work consists of two logical parts: the first part examines the issue of "locus" i. e., the presence of the Baltic Germans in the territory of Latgale. The second part focuses on protagonists and their interaction with the surrounding people. In the course of the study of the text, the geographical and personal details of the names and individuals mentioned were clarified, the intermediate conclusions were compared with the stated studies. The archives of Herder-Institut (Marburg, Germany) were used as additional sources.

\section{Results}

The book of Alexis von Engelhardt Die Kavaliere von Illuxt (Engelhardt, 1949) can raise interest for investigation of the lifestyle of the Baltic Germans living in the territory of contemporary Latvia and, in particular, the Latgale region. The title of the book bears two important aspects of the image: locus and people. Individual episodes of the book go back to the $18^{\text {th }}-19^{\text {th }}$ centuries, the exact dates are important to the author only to enhance the effect exactness. The renaming of former German names into Latvian names is an obstacle to deeper immersion in the study for general public. The analyzed book makes it possible to give historical facts a personal character, which is particularly important for launching tourist routes through Latgale and for organizing visiting lectures in schools and higher education institutions. A significant outcome of the study is the replenishment of joke texts and fascinating stories of the Baltic Germans known as Pratchen as the structure and content of individual episodes of the book correspond to their main characteristics.

\section{Discussion}

Alexis von Engelhardt, whose book is the object of the present research, was an offspring of a famous baron dynasty whose members were well established and respected in both Russia and Germany. The family was very big, the kinship very confusing. Numerous attempts to reconstruct the kinship relationship proved unsuccessful due to variations in spelling of the proper names both in Russian and German, which led to even greater confusion. Several members of this family hold leading civil service positions 
in the Russian Empire, to which modern Latvia belonged for long time. Some Engelhardts had a literary bent as well as engaged in world history and technical inventions.

Alexis von Engelhardt was born in 1868 at Lautzen, near the city of Daugavpils, and passed away near Berlin in 1954. He was a writer, journalist and editor. His most famous works include, first of all, history studies, such as Die deutschen Ostseeprovinzen Russlands, ihre politische und wirtschaftliche Entwicklung (1916) and Der König von Korsika und der Freiheitskampf der Korsen (1928) ( in German).

It is evident from the title of the analyzed literary work, written in the German language, that there are two concepts in the writer's focus, in particular, the characters identified in the given work and referred to as Kavaliere and the locus, i. e. the town of Illuxt, today Ilūkste, which has about 2,500 inhabitants and is located $25 \mathrm{~km}$ from the city of Daugavpils and $250 \mathrm{~km}$ from Riga, the capital of the Latvia. The city is situated on the crossroads of trade routes between the West and the East, in the immediate vicinity of the borders with Belarus and Lithuania, which predefined its history and development. The first mention of the city dates back to 1550 . Once a busy trade and border city it was severely damaged during the First and Second World Wars, as evidenced by numerous photographs of the old city on the Internet.

The city of Ilūkste has always been considered a multi-ethnic city. The fact that Germans resided there along with other nationalities follows from the analysis of the official home page of the city, which mentions that in 1798 in the city there was established Hauptmannschaft (Gendarmerie) for Illuxt, and the very concept and name of the city were given in German. On this basis, it can be assumed that the Germans occupied a leading position in the city, i. e. residing and actively engaging in social and economic activities. The current population census shows that the Germans among the modern Ilūkste population are not separately defined and belong to a group of representatives of different national groups, which accounts for 5 per cent of the total population of the city.

The book Die Kavaliere von Illuxt complemented with the title Erinnerungen aus dem Gottesländchen gesammelt von einem Alten Kurländer (Memories of a divine country collected by an old Courlander) consists of a short preface and eight chapters, four of which reveal the author's direct relationship with the characters depicted in the story: uncle Jasha (Onkel Jascha), uncle Reihnhold (Onkel Reihnhold) and der Letzte Maidenau (uncle Reihnhold and the last Maidenau), uncle Magnus, uncle Leopold (Onkel Leopold). A large number of relatives in the headings of the chapters gives an impression of the author's extensive affinity around Illuxt; as regards the district itself, according to the author of the book, it was commonly referred to 
in jest as "Duchy Engelhardt" (Engelhardt, 1949, p. 5). With reference to the Courland Journal of Civil Status Records published in 1977, it can be argued that members of the Engelhardts are recorded in the Church of Illuxt at least seven times at the beginning of the $19^{\text {th }}$ century, among the estates owned by the family are mentioned Lautzen, Brüggen and Lassen (Wildemann, 1977). These data confirm a large number of the Engelhardts.

The word Kavaliere at the beginning of the foreword to the book is provided with the synonym Edelleute (noble people, nobles), which corresponds to an article entry of a German language dictionary. The remaining chapters of the book comprising 79 pages expand the narration to the historical picture of a small town and its suburbs in the $19^{\text {th }}$ century: "Die grüne Dame" (Green Lady), "Die vier Brüder Sacken" (Four Brothers the Sackens), "Pastorengeschichten" (Pastorals), "Der alte Oettingen" (Old Oettingen).

The subtitle of the book deserves special consideration: by the time of publication in 1949, the author was 81year old; with full right, he calls himself an old recruit. After a severe war, after all the loss, pain, and suffering, the author in his memories returns to the time that seemed happy and carefree.

This book may be of interest to a modern reader used to skimming the headlines as these stories are stories of old times, offering easy and entertaining way of narration. The portrayal of welfare, brief but exact characteristics of the characters and events presented, the witty descriptions of certain habits and customs are of particular importance to the inhabitants of modern Latgale, as the book recalls and describes the localities in Latvia and, in particular, Latgale. The Latvian Selling campaign of 1937-1938 led to the fact that a contemporary resident of Latgale does not associate the old names of the human settlements cited in the book with the places familiar to him. The table that follows is a table of German names, current names of the populated areas, and the level of preservation of former names.

As shown in the Table 1, there are renovated buildings that are currently being maintained as culture centres or self-government buildings. Partially preserved properties are not being used, but it is also possible to see the remnants of former dwellings and economic buildings. The Alt-Grünwald and Meddum have not survived. It should be noted that the residents of Daugavpils, currently the largest Latgalian city are not aware of the former properties; however, the development of domestic tourism in Latvia caused by the restrictions of the corona-virus pandemic in 2020-2021 has awakened interest in the history of the native region. The questions regarding the former property owners are often not answered, or information about them is very scarce. 
Table 1. Buildings of former estates in Latgale

\begin{tabular}{|l|l|l|}
\hline Former name & Current name & Preserved extent \\
\hline 1. Illuxt (p. 5) & Ilūkste & \\
\hline 2. Alt-Born (p. 7) & Vecborne (district Krāslava) & partly \\
\hline 3. Brüggen (p. 9) & Briǵene (district Daugavpils) & partly \\
\hline 4. Alt-Grünwald (p. 16) & Vecgrīnvalde (district Ilūkste) & non-existent \\
\hline 5. Lautzen (p. 17) & Laucesa (district Daugavpils) & partly \\
\hline 6. Dünaburg (p. 25) & Daugavpils & \\
\hline 7. Tabor (p. 26) & Tabore (district Daugavpils) & non-existent \\
\hline 8. Kurtzum (p. 36) & Kurcums (district Daugavpils) & updated \\
\hline 9. Alt-Lassen (p. 48) & Veclaši (district Eglaine) & partly \\
\hline 10. Kalkuhnen (p. 53) & Kalkūni (district Daugavpils) & partly \\
\hline 11. Schedern (p. 58) & Šēdere (district Ilūkste) & updated \\
\hline 12. Meddum (p. 74) & Medumi (district Daugavpils) & non- existent \\
\hline 13. Schloßberg (p. 7) & Pilskalne (district Ilūkste) & partly \\
\hline
\end{tabular}

This information can be supplemented and revived by the book Alexis von Engelhardt, which is expanding our present cognition of the lifestyle of Germans in Latgale. It should be noted that the official information on the public Internet pages is often different from the memories of Alexis von Engelhardt, which gives these records additional value.

As Alexis von Engelhardt narrates, his parents' family lived in Lautzen (Laucesa), near Dünaburg, then a large city. The estate was rich, had good soil, many gardens and fields. All food provision was stored in several storehouses (Engelhardt, 1949, p. 38). The old gardener writes about the special fragrance from sorted apples in the baroque lattice oak cabinets (Engelhardt, 1949, p. 74). The description of reception by one of the many guests mentions some of the rooms in this house. It is clear that the owners of the estates received their particularly distinguished guests on the veranda (Engelhardt, 1949, pp. 17-28). The father's working office, named Schreibzimmer, was found at the end of a long master's house. In this room, apart from the typical furniture for the room in which the records were kept, a wide Divan was located, covered with fur, which apparently served for the master's rest. This was the most quiet place in the estate, which can be read from the description of the deep, calm sleep of one of the relatives visiting the author's father. There was one spacious room in the house where one could dance. Birthdays and weddings were celebrated there (Engelhardt, 1949, p. 53). The man was $2.16 \mathrm{~m}$ tall being the tallest Courlander of his time. In general, the trend reported by Ants Hein, while 
studying the features of the interior decoration of estates in the $19^{\text {th }}$ century, has not bypassed Latgale (Hein, 2006). In addition, there is no division into non-ceremonial rooms and personal chambers, rather the rooms with a clearly limited function, such as a lobby, hall, dining room, bedroom, etc.

A description of the multitude of estates is supplemented with a description of parks, for example, in Lautzen (Engelhardt, 1949, p. 74) or Alt-Lassen (Engelhardt. 1949, p. 46). After describing the park with its long-standing leaves and oak trees in Alt-Lassen, the author moves to the description of the home library of uncle Magnus, located in a white house similar to a palace. Large fertile fields were visible from the library window, as the house itself was located on a high-level pagan hill. Alexis, a small boy, with a tremor was examining the very building of a huge library with gothic vaults, ancient phonies, weapons, archaeological discoveries, and minerals in huge closets. An elderly man could get the curious boy interested with his endless legends and tales of his home country. In the middle of one wall there was a huge fireplace, and a tall leather chair of the master was standing in front of it. In the park there was a coloured geological profile of Courland, made of various rock and soil types. The book mentions that an old stone church was seen from the library window. The biggest mystery associated with this property concerns the question of why this property belonged to the Tiesenhausen kin, as recorded in all official reference books of modern Latvia. The old uncle was childless. After his death, none of the many relatives wished to take possession of the estate, so the estate was sold (Engelhardt, 1949, p. 61). In addition, the memoir manuscripts of the Baron Erich von Engelhardt, found in the archives of Herder-Institut (Marburg, Germany), mention that in 1928 a beautiful fireplace was stolen from the Tiesenhausen's house in Latgale (Herder-Institute, Archive file Nr. DSH 110 Engelhardt 17). This is probably the case of uncle Magnus, described above, from Alt-Lassen.

The author elaborates on the description of several other estates in which close and distant relatives of the Engelhardt family lived. Special mention should be made of Alexis's closest neighbor and university friend August von Oettingen (1823-1908), Lifland Landmarchal, Governor of Lifland, and later the mayor of Riga, who lived in Meddum. A man belonging to the highest strata of society loved his provincial estate. In the book Alexis von Engelhardt there is no description of this estate as Oettingen was more frequently on duty in Riga and Dorpat, which made it difficult for old university mates to keep in touch. The estate did not survive. A local school was built from the stones of the master's house, but a beautiful old park has survived.

From the above analysis, it is clear that the book is not so much about the city of Illuxt but rather the numerous estates nearby. The city itself 
also found its place in Die Kavaliere von Illuxt. From the memories of Baron von Budberg (Budberg 1958), it is clear that the Engelhardts have been in charge of the city and the entire Illuxt district since the second half of the $19^{\text {th }}$ century, indirectly confirming the definition of "Duchy of the Engelhardts". The certificate of German descent for Rudolph Baron von Engelhardt, issued by the Courland Noble Society in 1934, lists numerous relatives who lived on the estates near Illuxt.

The town of Illuxt had its notable place on the map of Latvia, as there was a city council, court and other authorities in the town (Engelhardt, 1949, p. 6). Fairs were held in the city, which brought merchants from different close and distant places. The living room in the central square was famous for its excellent cuisine and excellent Hungarian wine for dessert. The old photographs of the city convey its originality.

Latgalian metropolitan area has always been associated with Dünaburg (Daugavpils), the largest city in the region. A five-fold mention of the city on the pages of the small book implies that Dünaburg had the power of attraction of a large city for all people in the region, including the landowners, should one speak of the necessary purchases or entertainment. In addition, the city was also a fortress, which was remortgaged and often inspected during construction by the Russian Emperor Nicholay I. One of these visits, presumably before the beginning of the Crimean War in 1852, is narrated in Die Kavaliere von Illuxt (Engelhardt, 1949, p. 44). With admiration, the author describes the appearance of the emperor, his conduct, and the few words pronounced. The importance of the fortress for the city is especially emphasized as a fortification modern for that time with a significant artillery arsenal and huge reserves of weapons and food. (Engelhardt, 1949, p. 43).

Observations made in connection with the analysis of the estates and cities mentioned in Alexis von Engelhardt are important in understanding the presence of the Germans on the territory of one small area of Latgale. According to the first official data of the first census of the Russian Empire in 1897, 1.8 per cent of ethnic Germans lived in the Daugavpils district (Benz, 1998). Residing in their own estates, the Baltic Germans supported kindred and friendly ties with each other and engaged in civil service, primarily in the cities of Dünaburg and Illuxt. The main area of their life remained the estates in which the life of several generations had passed. Not only does the author describe the life of his family, but also recalls special occasions, conduct, and manner of communication with each other and with others.

The second important aspect for the analysis of this work is people, Kavaliere, i. e. as perceived by themselves and by other people. This aspect is particularly important for the understanding of the mentality of the Baltic 
Germans, who lived, in particular, on the territory of Latgale. Despite the fact that the author of the book narrates about individual representatives of his large family and friends, the analysis of the narration provides for a number of important generalizations to be made.

According to the diachronic structure of the book, the story begins with a legend of the "green lady" from the Engelhardts family and ends with the story of August von Oettingen, who was not related to that family. A unifying sense of pride in the "real Oberländer" (residents of the southern part of the country), who have the power of will and sense of honour, becomes the main point. It can be argued that the author deliberately leads the reader to the conception of common features of the Baltic Germans of Latgale by narrating specific events and characters.

By depicting the external features of the Engelhardts such as being tall, their special manner to wear broad old-fashioned coats, the author expresses the way they are perceived in another part of Latvia, in the city of Mitau (Jelgava), where a large number of Baltic Germans traditionally lived. According to the writer Eduard von Keyserlingk, quoted in Die Kavaliere von Illuxt, the Engelhardts produced an unforgettable impression of not being Germans in the eyes of German nationals, but rather partly Polish or Russians. Their closeness to the land is especially emphasized, hinting at the ownership of estates and noisy behaviour in society, their physical strength and a greeting with a threefold kiss in the Polish-Russian manner (Engelhardt, 1949, p. 5). It should be noted that Latgale is now considered too "Russian" which is linked to the high percentage of the Russian-speaking population and the proximity of the common border with the Republic of Belarus and the Russian Federation.

It should be noted that Alexis von Engelhardt names officers ranks and positions of the Engelhardts in the city hierarchy, highlighting their high social position and respect in all sectors of the society. Describing Onkel Jascha, the author points to the patriarchal style in the treatment of the peasants, who received advice and assistance, as well as his generosity toward them. It should be noted that no specific examples are provided. On the contrary, the author concentrates on the fact that it was common for the landowner to sexually exploit peasant women, which is why bastards, similar to the baron and to each other, appeared in neighbouring villages.

With special pride, Alexis von Engelhardt tells about his fellow countrymen and relatives who were in the service of Russian emperors. Guards officers from his family and acquaintances participated in the war against Napoleon some of them died in the Battle of the Nations near Leipzig or were wounded in the wars waged by the Russian Empire.

It can be claimed that Alexis von Engelhardt not only draws on his memories, but also uses the material of some family jokes about images 
depicted. In this, his memories are attaining the stylistics and structure of the above-mentioned Baltic jokes (Pratchen). Pratchen were intended as oral narrations for a large family or/or close friends. A determining condition for the relevance of such jokes and fascinating stories was that their object and the main character had to be familiar to the audience at the time of performing the Pratchen (Kaehlbrandt, 1995). The author repeatedly describes the admiration and surprise of his vast family because of unexpected decisions and the conduct of such eccentrics. The analysis of the private collection of the Baltic Pratchen, based on numerous sources and 174 texts, showed that, unfortunately, there was no single joke among the published texts dedicated to the Baltic Germans living in Latgale. This fact clearly shows the withdrawal of Latgale from the body part of Latvia in mental sense. In this case, the only source of the Baltics jokes about Latgale is Alexis von Engelhardt.

Most of the situations in which "eccentrics" appeared represent the Baltic Germans as people of honour and loyalty to their cause. These general mental characteristics, raised from childhood, are seen both in domestic situations and in the episodes with the characters representatives of nobles and authority. The episode with the Sacken brothers (Engelhardt, 1949, p. 22) shows that no action aimed at humiliating a person's dignity would go unpunished should representatives of the Baltic Germans were in presence. In this scene, a Polish tavern visitor taunts the small stature of one of the brothers. The two trays provided by the Polack pass without consequences, because the brothers were never, sure of a deliberate action for the first time, and for the second time they left the culprit an opportunity to apologize or abandon his foolish actions. After the third trait, the Polish ridiculer was forcibly placed outside the inn. It should be noted that this is the only case when a representative of another, not German nationality, is negatively portrayed in the book. An introductory legend about Anna Sibylla, married to a Polish military officer, is an example of balance. The next chapter contains the story of a matchmaking of the son of one of the aforementioned Sacken brothers (Engelhardt, 1949, pp. 24-35). A proposed bride was a daughter of a Polish landowner who lived in Lithuania close to Dünaburg. The description of the reception, the acquaintance, the joint meal and the matchmaking show that, generally speaking, for the German and Polish landowners of that region the nationality did not play a significant role in the case of formation of the family should it lead to a possible enrichment and increase of the estate. In this example, it can be seen that communication was based on mutual respect and common interests, even though the father of the future bride, who is ill-speaking and understanding in German, pronounced four times the words "Drang nach Osten!"(German: Spread to the East), which was perceived by the 
characters of this chapter with humour and without resentment. This claim can be illustrated by a quotation from Ernst Engelhardt's letter dated 1934 implying no importance was given to national differences in the rural areas (Herder-Institute, Archive file Nr. DSH 111 Engelhardt 30).

It should be noted that the slogan "Drang nach Osten!" was used by Julian Klaczko (1825-1906), a Polish journalist born in Vilna, in his pamphlet in the German language in 1849. The slogan was later taken over by the Pan-Slav Publicists, who sent their criticism against the Baltic Germans, whom they considered colonists and invaders (Henzel, 2014). It can be concluded that the Polish man was familiar with Julian Klaczko's pamphlet, which, however, did not prevent him from getting in engagement with the family of the Baltic Germans. In the description of the matchmaking, the names of numerous dishes and drinks representing various national cuisines, such as Piroggen, Gurjewskaja Kascha, Schaschlyk, Jameika-Rum, Sherry, etc. are mentioned. This diversity can be explained in terms of the lifestyle of the landowners who were open to new dietary impressions and the mixing of cultures of different nationalities living in the region. The peculiarity of Latgalian cuisine is also apparent in our days comprising all kinds of dishes that come from different national cuisines, such as German, Lithuanian, Jewish, Russian, Belarusian, etc.

With reference to Alexis von Engelhardt, it was not a custom among family and friends to issue debt receipts if some of them needed funds and sought help, eager to borrow money (Engelhardt, 1949, p. 74). The main seal was in this case the given word or agreement, which was a true honour. It was also a matter of honor to help the impoverished single family members who moved from estate to estate, where they received a bed, food, clothing and, in general, a comfortable existence. But this poor relative was required, in turn, to respect external propriety, understanding his place in the "foster" family. Mr. Maidenau violated this unspoken arrangement, for which he was permanently separated from the house of Uncle Reinhold (Engelhardt, 1949, pp. 42-47).

For the author of the memoires, the same object of pride is the episodes with August von Oettingen (1823-1908), the former Governor of Lifland and the city mayor of Riga, which took place in the days of the Russian Empire in the territory of the modern Baltic states. Speaking to the Russian Emperor Alexander II in Riga, Oettingen addressed the representatives of the Baltic knighthood in German, displeasing the Russian officials present (Engelhardt, 1949, p. 75). At the time of Russification under Emperor Alexander III Oettingen defended his right and the rights of the Baltic Germans to preserve their national identity. Alexis von Engelhardt cites a conversation between August von Oettingen and the then Minister of Internal Affairs of Russia, in which the Minister expresses his displeasure 
at the protests of the Baltic Germans against conducting business only in Russian. "You, after all, are Russian!" said Minister to Oettingen. What was followed by Oettingen's witty reply: "This is new to me. We are loyal German subjects of the Russian Emperor. I have never seen a noble stallion standing in a sheepskin turn into a sheep" (Engelhardt, 1949, p. 77) (translation mine - V. T.) It should be added that love of descent, in this case, to modern Latvia, is a common place in the image of the author of memoires. For example, he recalls numerous meetings at uncle Magnus estate, who encouraged young Baltic Germans to study the history of German knighthood in the Courland and Livonian provinces of the Russian Empire and to continue the traditions of their ancestors on their native land poured with blood and sweat (Engelhardt, 1949, p. 49).

Among the stories narrated by Alexis von Engelhardt with unchangeable pride, there are also such ones, which show the Baltic Germans as representatives of privileged layers of society, such as the landowners, owners of real estate, badgers, and servants. In addition, not always the admiration of the author corresponds to the perception of the ordinary people. The legend of Anna Sibylla tells that after the death of her first husband, the landowner rode a cow like a ghost, as the peasants from her estate said. The peasants understood the sorrows of the mistress, but attached a mystical meaning to the external manifestations of mental anguish, fearing the domineering mistress.

Uncle Magnus, a lover of his native land and history, was not the only one hot-tempered character "of course" (Engelhardt, 1949, p. 54).The author of the memories gives a few examples related to this relative that depict the uncle as a violent vigilante. For Alexis von Engelhardt, a man who saw Europe, who lived in Germany of the twentieth century, these episodes are unpleasant, but he is trying to justify his uncle's brutal behaviour toward his servants as a means of "education system" (translated by me - V. T) (Engelhardt, 1949, p. 50). The author applies his favourite technique to create a literary text, namely, the situation with negative connotation is followed by a kind of insignia or resolution. In this case, this is an episode with the coachman Adamka, who did not allow himself to be beaten because of the overthrown carriage. The writer points out that Adam is a former Russian soldier, and uncle Magnus is a former knight. The situation revealed a conflict between the owner and the servant, where both considered themselves worthy of contenders. The conflict had to be resolved by duels, in line with the Knight Code. The coachman, however, cling to the mother's memory, refused to make the first shot. The story ends with uncle Magnus sending the former coachman with an accompanying letter to another relative for whom he was recruited (Engelhardt, 1949, p. 52). It is not hard to imagine that in the eyes of the servants and 
the badgers, such behaviour of the master caused rejection and outright ridicule. The latter is particularly evident in the case of the construction of the railway station in the territory of uncle Magnus. Without accepting the industrial development of the country by refusing to use the railway, he became the subject of ridicule and jokes. When asked why he took a gun with him when visiting the railway station, uncle Magnus replied that he would have shot at the passengers of the train if they had started making faces at him (Engelhardt, 1949, p. 54). The cruelty and injustice in the treatment of the servants was balanced by the fact that rigid and violent offenders were fully subordinated to their clever and cunning wives, as Alexis von Engelhardt points out (Engelhardt, 1949, p. 55). The "eccentrics" of the characters depicted in many ways is borderline with madness and permissiveness, which Alexis von Engelhardt tries to show with humour and joke, for example, the habit of one of the relatives to shoot starlings with a gun at any place and at any hour (Engelhardt, 1949, p. 64). All these observations provide for the conclusion that the attitude toward such eccentrics within the family and friends was fundamentally different from that of the common people.

One story referred to in Alexis von Engelhardt stands out from the rest of the stories in that it is not about relatives, but rather about pastors in Courland. This story allows for a more generalized view of the situation of Baltic Germans in the territory of modern Latvia. The episode reveals, first and foremost, the relationship between two friends in different social positions. In the framework of the aims and objectives of the given article, it should be pointed out that the German pastor is shown far from the needs, concerns and interests of the common people, which is manifested in particular in the situation in which the German pastor, after finishing his first sermon for the German flock, continues his sermon for the Latvian parishioners without noticing that they had left shortly, and the church should be closed. Although the author tries not to focus the reader's attention on injustice or neglect of common people, the narrated text provides an overview of how the Baltic Germans were perceived in Latgale.

\section{Conclusions}

Alexis von Engelhardt Die Kavaliere von Illuxt is currently the only source of jokes and fascinating stories (Pratchen) of the Baltic Germans. Based on the life realia described above, it is possible to reconstruct the welfare of the people who disappeared from the map of modern Latgale. The Baltic Germans lived in Latgale for several generations, most of them were landowners. For the peoples who inhabited Latgale in the $18^{\text {th }}$ and $19^{\text {th }}$ centuries, the national issue was not decisive, especially among rural 
people. Difference in perception of oneself and "myself in the eyes of others is determined by different social status: Germans are the landowners, the rest are servants and badgers. The mental character of the Baltic Germans determined, first and foremost, family upbringing and education level, commonly university. The main concepts were love for their native land, pride for their ancestors, honour, and service to the state, faithfulness to the word.

\section{Acknowledgment}

The research is funded by the Latvian Council of Science, project "The Baltic Germans of Latgale in the context of socio-ethnic relations from the $17^{\text {th }}$ till the beginning of the $20^{\text {th }}$ century", project No. lzp-2020/2-0136.

\section{References}

Archive file nr. DSH 110 Engelhardt 17- Marburg: Herder-Institut Archive. [14.08.2019]. [In German].

Archive file nr. DSH 111 Engelhardt 30, 11.12.1927 - Marburg: Herder-Institut Archive. [16.08.2019]. [In German].

Benz, E. (1998). Zwischen konfessioneller, regionaler und nationaler Identität. Die Katholiken in Lettgallen und Lettland im 19. und 20. Jahrhundert. [Between denominational, regional and national identity. The Catholics in Latgale and Latvia in the $19^{\text {th }}$ and $20^{\text {th }}$ centuries.]. Nordost-Archiv, VII, 2. Lüneburg: Institut Norddeutsches Kulturwerk. [Northeast Archive, VII, 2. Lüneburg: Institute of North German Cultural Work], pp. 393-495. [In German].

Budberg von, N. (1958). Im Schatten der Toten (Aus baltischer Vergangenheit 19181920) [In the shadow of the dead (From the Baltic past 1918-1920)]. Aichach: Mayer \& Söhne. [Aichach: Mayer \& Sons], pp. 66-67. [In German].

Engelhardt, A. (1949). Die Kavaliere von Illuxt. Erinnerungsblätter aus dem Gottestländchen gesammelt von einem alten Kurländer. [The cavaliers of Illuxt. Souvenir sheets from the Gottestland collected by an old Kurlander]. München: Heimeran. [In German].

Hein, A. (2006). Zeit und Raum. Innengestaltung Est-und Livländischer Herrenhäuser während der zweiten Hälfte des 19. Jahrhunderts. [Time and space. Interior design of Est- and Livonian mansions during the second half of the $19^{\text {th }}$ century]. Baltische Seminare, Band 7 "Baltische Gutshöfe". Lüneburg: Carl-Schirren-Gesellschaft [Baltic Seminars, Volume 7 "Baltic Manors". Lüneburg: Carl Schirren Society], pp. 259-282 [In German].

Henzel, F. (2014). Stalins Grenzziehungen im besiegten Deutschland 1945. Zur kolonialistischen Genese zweier slawisch legitimierter Siegeszeichnen [Stalin's drawing of borders in defeated Germany in 1945. On the colonial genesis of two Slavic legitimized signs of victory]. Norderstedt: BoD, p. 30. [In German].

Kaehlbrandt, L., (1995). Baltische Pratchen und andere heitere Geschichten von Balten seit der Umsiedlung 1939 [Baltic jokes and other cheerful stories from the Balts since the resettlement in 1939]. Köln: Mare Balticum. [In German]. 
Wildemann von, C. W. (1977). Kurländisches Traubuch [the Courland Civil Registry Book]. Beiträge zur Baltischen Geschichte, Bd.8 [Contributions to Baltic History, Vol. 8], Hannover-Döhren: Hirschheydt. pp. 21-27. [In German]

Wilhelmi, A., (2008). Lebenswelten von Frauen der Oberschicht im Baltikum (18001939). Eine Untersuchung anhand von Autobiografien. [Living worlds of women of the upper class in the Baltic States (1800-1939). An investigation based on autobiographies]. Wiesbaden: Harrassowitz. [In German]. 